\title{
ENTRE A NOBREZA DO TALENTO E A DOS PERGAMINHOS: A SOCIEDADE PORTUGUESA EM TRANSFORMAÇÃO SOB A ÓTICA DE GUIOMAR TORRESÃO EM UMA ALMA DE MULHER
}

Juliana de Souza Mariano

Chegou o momento em que cumpre dizer-te, és uma senhora, e como tal devo apresentar-te no mundo [...]. Guiomar Torresão ${ }^{1}$

Resumo: Neste artigo, analisamos o livro Uma alma de mulher, de Guiomar Torresão, publicado em 1869. Sob uma costumeira história de amor impossível, escondem-se importantes reflexões não só sobre o campo dos afetos, mas também sobre uma sociedade em transformação, composta por conflitos de classe e gênero. $O$ estudo da obra se baseará, portanto, na análise desses conflitos que permeiam, em maior ou menor grau, a narrativa.

Palavras-chave: Guiomar Torresão. Autoria Feminina. Literatura Portuguesa. Século XIX.

Abstract: In this article, we analyze the book Uma alma de mulher, by Guiomar Torresão, published in 1869. Under a typically impossible love story, brings important reflections not only on the field of affection, but also on a society in transformation, composed of class and gender conflicts. Therefore, this study will be based on the analysis of these conflicts that permeate, greater or lesser degree, all the narrative.

Key-words: Guiomar Torresão. Female Authorship. Portuguese Literature. 19th Century.

Guiomar Delfina de Noronha Torresão (1844-1898) lançouse no mundo das letras com pseudônimos masculinos. Era uma maneira de preservar sua identidade e garantir a leitura de seus textos, uma vez que o espaço da escrita não era

1 TORRESÃO, Guiomar. Uma alma de mulher. Lisboa: Typographia de J. G. de Sousa Neves, 1869. 
propício às mulheres. Dessa forma, assinou como Gabriel Cláudio, Delfim de Noronha, Roseball, Scentelha, Sith, Tom Ponce. Depois de familiarizar - e fidelizar - o público com sua escrita, é que revelou sua identidade, passando a assinar seu próprio nome.

Dramaturga, publicista, jornalista, ensaísta, cronista, tradutora, romancista, poetisa, teve a escrita como meio de subsistência, fato extremamente raro para uma mulher. Oriunda de uma família pobre, Torresão precisou, desde muito nova, ajudar no sustento do lar. A princípio, como professora particular e, posteriormente, como redatora de jornais. Portanto, para ela, escrever não era um simples passatempo. Como aponta Fialho de Almeida,

Guiomar Torrezão não tinha pae nem irmãos que exigissem contas aos desrespeitadores eméritos das mulheres sós; e não tendo constituido familia, nem tendo fortuna própria, achou-se na condição de ter que ganhar ela mesma o seu prato e os seus vestidos, escrevendo para jornaes todos os dias - isto é, cosendo á penna, em vez de coser á machina, e não tirando deste esgotante martyrio sequer talvez o que as pobres costureiras auferem nos armazens onde trabalham. (ALMEIDA, 1923, p. 189)

Estreou nas letras em 1868, com o romance Uma Alma de Mulher, publicado em folhetim no jornal A Voz Feminina 
e em livro no ano posterior. Da extensa e variada produção literária de Torresão, destacam-se Rosas Pálidas, livro de contos e novelas publicado em 1872; o romance histórico A Família Albergaria (1874); Meteoros (1875), antologia de crônicas, contos, críticas literárias, notas de viagens que escrevera em diversos periódicos; O fraco da baronesa (1878), comédia em um ato; No teatro e na Sala (1881), um conjunto de escritos, contos, teatro e crítica literária. Na carta-prefácio da obra, Camilo Castelo Branco revela o estigma que recai sobre as escritoras, alvos de severo julgamento da crítica, muitas vezes indulgente quando analisa uma obra masculina.

Aqui, n'este paiz -como v. exa decerto não crê- ha tanto lyrismo e tamanha necessidade de o exhuberar em caçoulas de perfumarias, que os lyricos, se uma senhora se faz, em vez de idolo, sacerdotiza- em vez de poetizada, poeta- logo se consternam [...]

Parece, todavia, que elles, os letrados, se temem d'isso, a julgar pela malquerença com que os veja contender com poetizas e romancistas!

Publica-se tanta parvoiçada do meu sexo licenciada e gabada pela critica!

Inliçam-se e subornam-se tantas condescendências entre os mestres da arte e os remendões que recortam tombas em 
velhas botas de escriptores esquecidos ou obscuros para armarem lenda de feira da ladra sem que lhes grite a consciência da ladroeira! (CASTELO BRANCO, 1881, p. 5-6)

Conhecida como "operária das letras", Torresão publicou textos em diversos veículos da imprensa portuguesa e brasileira, como Almanaque das Lembranças LusoBrasileiro, Diário Ilustrado, Ilustração Portuguesa, Diário de Notícias, O Mundo Elegante e a revista semanal Ribaltas e Gambiarras, da qual foi redatora. Em 1871, fundou o Almanach das Senhoras, que se tornou um importante instrumento de divulgação de autoras, o qual dirigiu até 1898 , ano de sua morte.

Contudo, sua quase onipresença no mundo da escrita esbarrou em críticas respaldadas por evidente machismo. Uma delas foi a de Ramalho Ortigão, que questiona a relevância do Almanach das Senhoras, depreciando o talento das mulheres que nele escreviam:

Acabamos de folhear do principio ao fim um numero do Almanach das Senhoras, que temos presente. Temos tambem presente a Gazeta das Salas, egualmente redigida por senhoras. Deus nos defenda de que qualquer extrangeiro procure julgar, sobre estas producções litterarias, do estado do espírito feminino na sociedade portugueza! Em todas estas collecções dos trabalhos intellectuaes das nossas mulheres - 
sentimos dizel-o - não ha um só artigo grave, sério, meditado, revelando conhecimentos práticos, aspirações elevadas, pensamentos nobres. De tantos problemas sociaes que affectam a condição da mulher na sociedade contemporanea e que solicitam a attenção d'ella, para serem resolvidos pela parte mais interessada e mais competente da humanidade, nem um só foi julgado digno do estudo de alguma das senhoras que fazem imprimir e publicar os seus escriptos em Portugal! Estas senhoras produzem [...] trovas de uma sentimentalidade de segunda mão, sem ideal, sem paixão, de uma pieguice grotesca. Escrevem tambem contosinhos ou novellas de amores infelizes, cujas personagens se tratam por excellencia e se requebram em artificios de um dandysmo cuja legitimidade está longe de poder ser absolutamente garantida, não dizemos já n'um congresso de gentlemen, mas n'um simples tribunal de cabelleireiros. E é para nos dar estes lamentaveis fructos da sua educação exclusivamente litteraria, que tanta menina honesta sacrifica o tempo que devia consagrar aos nobres trabalhos do ménage, tornando-se, em vez de uma digna mulher util, apta para acompanhar, para comprehender e para ajudar o homem, uma pobre e misera creatura neutra, desorientada da vida real, incapaz de qualquer emprego na vida prática, cheia de falsas aspirações, de desenganos e de tédios permanentes!

Assim temos que na Inglaterra e na Allemanha a eschola das ménagères 
produz as mais graves e mais importantes escriptoras. Em Portugal a educação litteraria, segundo os programmas dos lyceus, nem dá ménagères nem dá litteratas. (ORTIGÃO, 1889, p. 159-162)

O julgamento de Ortigão esbarra na leitura superficial dos textos das senhoras do Almanach e da própria sociedade. É muito provável que, se discutissem os "tantos problemas sociaes que affectam a condição da mulher na sociedade contemporanea" (ORTIGÃO, 1889, p. 159) de maneira explícita, fazendo de suas obras manifestos feministas, essas mulheres seriam mais marginalizadas do que já eram.

Havia incontáveis limitações à existência das mulheres na sociedade oitocentista. Uma mulher como Guiomar Torresão que, além de pobre, tornou-se uma escritora profissional, é uma exceção, podendo até ser vista como uma aberração. Esses obstáculos, no entanto, não Ihe calaram. Torresão contesta a análise de Ortigão, denunciando a educação deficitária e, ainda assim, restrita a uma parcela da população feminina portuguesa. Dessa forma, seria um equívoco comparar a qualidade da escritora estrangeira com a da escritora portuguesa, uma vez que esta é

privada de instrucção, sem nenhum curso superior que a habilite, sem o menor impulso que a encaminhe, sem um estimulo que a fortaleça; que ninguém lê, ninguém 
conhece, - e que pela voz eloquente e vibrante daquelles que, como o sr. Ramalho Ortigão, podiam e deviam nortear-lhe o espirito e conduzil-a ao Fiat lux emancipador, é simplesmente e rudemente apupada!!!

\section{$[\ldots]$}

Percebemos unicamente que o sr. Ramalho Ortigão, usando da prerogativa de critico absoluto, e considerando o lyceu um ultrage para a mulher intelligente, a sala um objecto de luxo para a mulher elegante, convida a intelligente, a espirituosa e a ignorante a recolher á cosinha, e promette fornecerIhes em compensação um curso completo de chimica culinaria. (TORRESÃO, 1881, p. 245-248)

Postura diferente da do autor das Farpas assumiu, anos antes, Julio César Machado, responsável pela Introdução do primeiro romance de Guiomar Torresão, Uma alma de mulher. O escritor, que se destacou como folhetinista e cronista, usa de sua "voz eloquente e vibrante" para "nortear-lhe o espirito e conduzil-a ao Fiat lux emancipador" (TORRESÃO, 1881, p. 245).

Machado faz uma contundente crítica acerca da educação feminina em Portugal. Para ele, o modo como as coisas se dão gera não só desperdício de tempo às mulheres, mas também contribui para o aumento da desigualdade intelectual e econômica entre os sexos: 
O que me impressiona e me commove, o que é digno de se ver e de se louvar, é que no nosso tempo no nosso paiz, no meio de Lisboa, onde as senhoras ainda que superiormente dotadas pela natureza estão condemnadas a uma educação acanhada, a uma hygiene moral deploravel, e á preoccupação constante de minucias que lhes atrophiam a intelligencia ao ponto de verem na moda e no traje as condições absolutas da felicidade: n'um paiz onde em todas as reuniões os homens e as senhoras estão divididos em grupos distinctos que não se entendem senão quando a paixão, o interesse, ou a vaidade os aproxima: n'uma terra que estabelece no seio da mesma mãe patria duas nações de seres differentes que não teem as mesmas crenças religiosas, nem o mesmo nivel de cultura intellectual, nem o mesmo codigo moral [...]. (MACHADO, 1869, p. 9)

Ainda assim, alguns talentos conseguem surgir. O autor destaca a coragem da mulher, que, a despeito de um sistema que a inferioriza e não lhe oferece condições nem meios para ascender intelectualmente, ainda assim ousa, sozinha, "fazer a sua sorte, o seu nome, a sua posição, o seu futuro, com o atirar aos ventos da publicidade as suas idéas, as suas phantasias, os seus sonhos, a sua imaginação e a sua alma!" (MACHADO, 1869, p. 9), como é o caso de Guiomar Torresão.

Se, por um lado, Machado mostra-se um forte aliado das mulheres, ao defender uma reformulação do currículo 
das escolas femininas, por outro, ele procura advertir que a literatura de Torresão não é resultado de um árduo trabalho intelectual, mas mero fruto da espontaneidade de "uma alma de mulher". Ainda que as palavras de Machado sugiram certos estereótipos de gênero, pois dá a entender que a escrita masculina pertenceria à esfera da racionalidade e a feminina, à da sensibilidade, devemos analisá-las com atenção.

O espaço da escrita era majoritariamente masculino. Assim, era comum que as mulheres que se aventurassem nessa área utilizassem certas estratégias que preservassem a sua reputação, como mecanismos de ocultamento pseudônimos -ou a chancela de algum escritor ilustre, que, com o seu prestígio, apresentaria a "menina" ao público leitor. Como aponta Ana Maria Costa Lopes, são "bemvindas as apreciações positivas provindas dos intelectuais masculinos que ou publicitam ou encomiam, em letra de forma, a obra de uma mulher ou a sua intervenção pública" porque "saem elas mais eficazmente da invisibilidade a que estavam tradicionalmente votadas" (LOPES, 2005, p. 256).

Dessa forma, ao utilizar adjetivos como "gentil" e "formosa" para caracterizar a obra de Guiomar Torresão, Machado garante que ela é inofensiva, pois não rompe 
com padrões já estabelecidos, e, por isso, poderá ser lida sem causar choques. Ao aceitar essa designação, Torresão garante que sua obra seja publicada e lida, o que é o anseio de todo escritor. Assim, ambos parecem construir certo pacto de sobrevivência.

Porém, Uma alma de mulher, obra que selecionamos para analisar neste capítulo, é inofensiva apenas na superfície. Sob uma costumeira história de amor impossível, escondem-se importantes reflexões não só sobre o campo dos afetos, mas também sobre a sociedade portuguesa do século XIX e seus conflitos de classe e gênero. O estudo da obra se baseará, portanto, na análise desses conflitos que permeiam, em maior ou menor grau, a narrativa.

Cecília é a protagonista e também a narradora da história. Isso já revela ao leitor que se trata de um relato pessoal, a partir da perspectiva particular dessa personagem. 0 próprio título antecipa o que iremos ler. Como narradorapersonagem, Cecília conduz o leitor pelo desenvolvimento de sua personalidade a partir das experiências vividas. Essencial para a construção da sua identidade é, aos 10 anos, a perda da mãe, o que nos é revelado já no primeiro parágrafo do livro. As consequências desse fato - que foi antecedido pela morte de seu pai - são profundas e refletem em todas as relações pessoais de Cecília: 
Apezar de que n'aquella edade os desgostos teem apenas a duração da espiral de fumo que o vento desfaz; recordo-me no entanto com indisivel melancolia a sensação que produziu na minha imaginação infantil, a ausencia d'essa luz divina, que se chama mãe. (TORRESÃO, 1869, p. 11)

Em vão, tenta suprir a ausência materna com a tia, sua tutora, a baronesa, que "fazia os maiores esforços, [...] mas os seus afagos assimilhavam-se mais áquelles que se dispensa ao fraldiqueiro estimado, do que os mimos prodigalisados ao filho estremecido" (TORRESÃO, 1869, p. 11).

A carência afetiva, preenchida pela leitura de romances, somada à farta imaginação de Cecília, moldam sua personalidade "sempre romântica" (TORRESÃO, 1869, p. 13). Como também é narradora, é sob o viés do Romantismo que as ações serão contadas e os personagens caracterizados.

Aos 16 anos, é chamada ao cumprimento de seu papel de "senhora". Por isso, é preciso deixar o Alentejo para frequentar os salões lisboetas com sua tia; ver e ser vista:

- Creança! esqueces que tens dezesseis annos, que é mister occupar a sociedade que te reclama, o logar a que tens incontestaveis direitos? Chegou o momento em que cumpre dizer-te, és uma senhora, e como tal devo apresentar-te ao mundo, sempre disposta a acolher com homenagens a quem é jovem, e feliz; a quem pode erguer a fronte 
resplandecente com a duplice aureola do dinheiro e dos pergaminhos. [...]A sociedade com a multiplicidade das suas fascinações, possue indubitavelmente mais aroma em uma só, do que o que todas as tuas flôres exhalam. (TORRESÃO, 1869, p. 13-14)

Fica evidente, na fala da baronesa, que os direitos de Cecília na sociedade são incontestáveis por causa de sua posição social: riquezas e títulos de fidalguia lhe conferem distinção. Como demonstra Irene Vaquinhas,

as formas de tratamento reflectem, pois, uma concepção elitista da organização social [...]. A burguesia desenvolverá ao longo do século XIX toda uma estratégia de distanciamento social relativamente ao "povo". Os Códigos de Civilidade, de grande sucesso editorial, têm precisamente a função propedêutica de ensinar regras e os comportamentos socialmente correctos e adequados a "gente de bem" contribuindo para definir o arquétipo de uma senhora. A discrição é, nesta matéria, a regra de ouro e a qualidade mais apreciada. Recato nas palavras, nos gestos, nas múltiplas formas de expressão. (VAQUINHAS, 2000, p. 15)

Ainda assim, Cecília exerce com estranhamento o seu papel de senhora naquele espaço. Criada no interior, a jovem tem hábitos e gostos simples; ignora, pois, os códigos de conduta do chamado "mundo elegante", conhecido apenas dos livros e da imaginação. A descrição, carregada de 
simbologia romântica, de sua iniciação no "grande mundo" (TORRESÃO, 1869, p. 15) revela mais que o seu desconforto; expõe o choque cultural entre província e cidade. Ou melhor, denuncia um espaço exclusivo, de uma minoria:

O scintillar de mil lumes, repercutidos em innumeros espelhos; ferindo raios multicôres na immensidade dos diamantes, que assimilhavam cada senhora a uma constellação; o perfume penetrante das flôres, dispostas com profusão pelas salas; a bellesa, a elegancia, o espirito da sociedade selecta, convidada pelo visconde de Castellões; as harmonias da orchestra, todo este conjuncto admiravel, era mais que sufficiente para deslumbrar um espirito juvenil e completamente alheio a essas diversões do mundo elegante. Cruzavam-se os ditos finos, e espirituosos. Cada mulher bonita tinha a sua coterie attenta e submissa ao menor olhar ou gesto da soberana absoluta. (TORRESÃO, 1869, p. 15-16)

A sensação de não pertencimento aumenta à medida que Cecília compara a vida citadina com a do interior e sente saudades desta. Na cidade, embora cercada de opulência, não se satisfaz completamente, contrariando aquilo a que a baronesa aspirava e planejava para a sobrinha, e também o que a sociedade esperava de uma senhora. Irene Vaquinhas aponta que a preocupação com a imagem exterior estava associada à classe dominante: 
O "meticuloso escrupulo do corte e do acabamento" do vestuário, a sua adequação ao tipo físico, à idade ou ao local onde se exibe, "a excelência dos tecidos" e sobretudo "pequeninas minudências" que implicavam a escolha criteriosa de "acessórios" (jóias, botões, sombrinhas, regalos, mitaines, etc) caracterizam uma mulher "verdadeiramente elegante", ou, de acordo com a terminologia da época, "uma senhora". (VAQUINHAS, 2000, p. 59)

Uma sociedade que prioriza as aparências vai de encontro ao que Cecília acredita. No entanto, ela sabe que não pode expor sua opinião, pois saber silenciar é característica essencial e necessária à vida de uma "senhora". Embora reafirme sua inexperiência a todo o momento, Cecília compreende que é preciso dissimular para garantir a sobrevivência.

Bem presentia eu, apesar da minha natural inexperiencia, o ridiculo a que me exporia se ousasse manifestar alguma d'estas saudades, e o motivo d'elas, a essa sociedade feminina que enchia as nossas salas, de ordinario preoccupada com futilidades taes como observar a coiffure da condessa $* * *$ ou, o que é peior os seus actos privados; ou esmiuçar os ultimos decretos transmittidos de Paris! discutindo-se a melhor praxe a adoptar para bem merecer perante o high life lisbonense a extravagante realesa da moda!! (TORRESÃO, 1869, p. 20) 
É nesse espaço conflitante, pois Ihe gera receio, fascínio e crítica, que Cecília, personagem-narradora, apresenta personagens importantes em sua história: Victor de Andrade, Georgina e o conselheiro. A caracterização de Victor, "um brilhante talento na pintura, um futuro Raphael" (TORRESÃO, 1869, p. 16), prenuncia suas ações futuras como herói romântico:

Transparecia-Ihe na fronte altiva e elevada, o genio que Ihe faiscava na mente, descerrando-lhe vastos horisontes. Observando-o, pareceu-me isolado, melancolico no seio d'aquell multidão loquaz; instinctivamente segui-o com um olhar de sympathia. (TORRESÃO, 1869, p. 16)

A "nobresa e melancolia do seu porte" (TORRESÃO, 1869, p. 21), atraíam Cecília. Seu amor por Victor, revelado mais tarde, parece ser uma combinação de dois fatores: a semelhança do rapaz com personagens de seus romances preferidos ${ }^{2}$ e o fato de ambos serem outsiders naquele espaço.

Por outro lado, o conselheiro não era descrito com a mesma benevolência: "Nariz proeminentissimo, separando uns olhos sem côr prefixa; labios grossos constantemente entreabertos com um surriso que poderia ser espirituoso, mas que só era complacente" (TORRESÃO, 1869, p. 21). É justamente com esse homem, por quem nada sente e cuja

2 Cecília era leitora voraz dos romances de Victor Hugo, Goethe, Chateaubriand. 
figura não Ihe agrada, que Cecília deve se casar. Michelle Perrot mostra que

a aliança e o desejo nem sempre concordam entre si - longe disso. O drama das famílias, a tragédia dos casais frequentemente reside nesses conflitos entre a aliança e o desejo. Quanto mais cerradas as estratégias matrimoniais para assegurar a coesão familiar, tanto mais canalizam ou sufocam o desejo. Quanto mais forte o individualismo, tanto mais ele se insurge contra as escolhas do grupo, os casamentos decididos ou arranjados. (PERROT, 2009, p. 119)

Já a caracterização de Georgina, embora revele traços românticos, como a palidez de sua pele e a meiguice de seu sorriso, apresenta elementos dissonantes, o que pode ser notado nos adjetivos grifados no trecho a seguir:

Era Georgina, minha prima; mais velha do que eu seis annos. Pallida, e loira; olhar morbido despedindo relampagos fugitivos; nos labios um surriso meigo, persuasivo, insinuante. No todo uma graciosidade inexprimivel. Logo á primeira vista impressionou-me agradavelmente. (TORRESÃO, 1869, p. 17-18, grifo nosso)

Embora de maneira sutil, Cecília-narradora fornece pistas ao leitor. Cabe a ele escolher entre desconfiar dos atos de Georgina ou acreditar em sua aparência angelical. Cecíliapersonagem, levada pela inexperiência e carência afetiva, 
confia plenamente na prima: "Desde a infancia que esse anhelo de todo o coração que como avesinha implume busca em cada affecto um ninho, me absorvia toda: e para elle phantasiava eu não sei que risonhos idyllios!..." (TORRESÃO, 1869, p. 18). Por outro lado, a Cecília-narradora tece o seguinte comentário, questionando o comportamento de Cecília-personagem: "Pobre orphã que até então carpira á mingua de affectos dedicados!" (TORRESÃO, 1869, p. 18). A jovem Cecília deixa-se, pois, levar pelo sentimento.

É também o sentimento que faz com a personagem ajude financeiramente Georgina, sua prima pobre:

quiria dia a dia tão fundas raizes, que não podiamos já viver uma sem a outra.

Dedicava-Ihe toda a minha alma com o enthusiastico abandono de uma affeição primeira. Minha prima era pobre, e essa circumstancia facultava-me a gloria de lhe poder ser util; buscando ao mesmo tempo todos os modos de agradar-Ihe. (TORRESÃO, 1869, p. 22)

As diferenças econômicas entre as primas não geram, a princípio, qualquer conflito. Ao contrário, parecem fortalecer ainda mais os laços, tornando-as inseparáveis confidentes. Contudo, ao descobrir que fôra prometida em casamento ao conselheiro, homem que não ama, Cecília sente-se, de certa forma, traída pela prima, que nada lhe havia dito. 
Cuidei que era victima de algum sonho mau!

Fervia-me na mente um turbilhão de idéas!

A indignação apoderara-se de mim patenteando-me bem claramente a maneira como haviam escravisado a minha liberdade, sem me consultarem sequer! tomando, ou simulando tomarem por affeição o que fizera unicamente por deferencia.

Parecia-me inexplicavel que Georgina nada me houvesse dito; que Victor!... (TORRESÃO, 1869, p. 27)

Também se sentia traída pela tia, que prometera assegurar sua felicidade:

Atravez do artificio com que minha tia, sem interrogar o meu coração, sem temer as terriveis consequencias do futuro, me tolhia a faculdade da negativa, percebi a ambição de conservar a todo o risco um administrador zeloso que em vez de diminuirIhe as rendas augmentava engrossando o capital; dando-me ao mesmo tempo um marido cuja fortuna colossal, e proverbial generosidade a collocava ao abrigo de quaesquer reclamações com relação ao meu patrimonio, provavelmente diminuido. (TORRESÃO, 1869, p. 27-28)

Cecília percebe que sua tia tem intenções meramente materiais. Ao arranjar o casamento entre a sobrinha e o conselheiro, a baronesa garantiria economicamente a sua posição de classe e, certamente também, a ampliação do 
patrimônio familiar. Não importava se o conselheiro seria um bom marido para a sobrinha, mas a certeza de que ele era um bom administrador de bens. Cecília era, assim, reduzida a uma mercadoria. Michelle Perrot mostra que

a família é a garantia da moralidade natural. Funda-se sobre o casamento monogâmico, estabelecido por acordo mútuo; as paixões são contingentes, e até perigosas; o melhor casamento é o casamento "arranjado" ao qual se sucede a afeição, e não vice-versa. A família é uma construção racional e voluntária, unida por fortes laços espirituais, por exemplo a memória, e materiais. O patrimônio é, a um só tempo, necessidade econômica e afirmação simbólica. (PERROT, 2009, p. 80)

Apesar disso, Cecília, nesse momento, não verbaliza sua indignação, pois sabe que uma senhora deve ser discreta. Além do mais, crê que Victor não a ama, já que interpreta a amizade entre ele e Leonor como uma corte amorosa. A personagem, porém, não é completamente passiva. Certa de que não lhe resta alternativa e impedida de elevar a voz contra a deliberação da tia, Cecília ousa ser honesta aos seus próprios sentimentos ao dirigir-se ao conselheiro:

A dôr, e o orgulho ferido, produziram em mim completa reacção: comprehendi que para fugir a um amor absurdo havia um único meio, o casamento. 
Occultando pois em um apparente surriso a angustia que me enchia o peito, disse á baroneza:

- Visto que tenho o coração livre, acceito sem grande sacrificio o partido que vossa excellencia me propõe; depois dirigindome ao conselheiro: Não the prometto amor, mas asseguro-lhe a constancia de uma amisade verdadeira. (TORRESÃO, 1869, p. 28)

Sua decisão é abalada quando surpreende Victor "nadando em lagrimas", "com a expressão de uma agonia impossivel de descrever!", mas ainda sim "bello como o Apollo de Belvedère; sublime de magestade como uma visão do Apocalypse!" (TORRESÃO, 1869, p. 30). Victor, figura triste e bela, encarna o sublime e, na perspectiva de Cecília, parece um grande artista evocando sua musa:

E que na melancolia, e na apaixonada expressão das feições de Victor havia um encanto mysterioso, indisivel! Pensando em Laura a physionomia de Petrarcha, deveria ser assim; a de Tasso evocando Leonor; Raphael sonhando com a Fornarina... (TORRESÃO, 1869, p. 31)

A resposta de Victor, sobre o motivo de sua tristeza, corrobora a imagem feita por Cecília. Tal qual um trovador, ele sofre por um amor impossível. Reconhecendo o peso que o dinheiro tem para as relações pessoais daquela sociedade, 
o pintor está fadado à dupla morte: moral e física, causadas pela pobreza.

- Desgostos! tornou Victor, é bem fraca essa palavra; na minha alma há tormentos dignos do inferno do Dante!

Sabe vossa excellencia o que é ter o coração a transbordar manaciaes de ternura, a entrever visões febris, n'esse primeiro arrobo a que Stemdhal chama crysthalisação; avistar o eden, voar para elle ebrio, fascinado, e de repente ter de recuar, e ser precipitado n'um cháos de sofrimento ao som d'esta palavra pobreza! Póde acaso comprehender que morte moral é a pobreza, vossa excellencia rodeada de esplendores?

$[\ldots]$

Sabe que quando se chega a isto não há outro partido senão a morte? (TORRESÃO, 1869, p. 32)

A revelação de que se amam, em vez de provocar esperança e alegria, parece aumentar ainda mais o sofrimento, pois não encontram formas de concretizar esse amor, que permanece no plano das ideias. Nas palavras de Victor, "oiro e pergaminho" são "barreiras insuperáveis" (TORRESÃO, 1869, p. 34). Assim, por mais que houvesse transformações - sem elas, por exemplo, Victor não teria conseguido se formar pintor e frequentar os salões-, riqueza e fidalguia ainda exerciam um peso grande naquela 
sociedade. Cecília também sabe que a realidade é bem diferente de seu sonho romântico:

O caracter de minha tia naturalmente ambicioso, eivado de todos os falsos preconceitos de uma aristocracia absurda, não admittindo por sentido algum a menor homogeneidade entre a nobresa do talento e a dos pergaminhos, tirar-me-hia toda a esperança, quando mesmo não existisse esse compromisso que tomára em um momento de allucinação. (TORRESÃO, 1869, p. 37-38)

Por isso, qualquer projeto de concretização amorosa permanece no plano da fantasia. É coerente com as características dos jovens enamorados que a Itália seja o destino de possível fuga:

É a minha patria adoptiva; a patria de todos os artistas, o berço de todas as artes.

$[\ldots]$

Felizes, amados, amantes percorreremos toda a cidade dos Cesares; admirando as reliquias do passado, comprehendendo-Ihes a mysteriosa poesia atravez da religião do amor! (TORRESÃO, 1869, p. 44)

No entanto, a fuga para a Itália é apenas um devaneio romântico, um escapismo diante da realidade penosa. Perante a recusa da amada, não insiste ou tenta convencê-la a fugir, mas acata sua decisão docilmente: 
$\mathrm{Na}$ expressiva physionomia de Victor transluzia todo o sentir da sua alma: comprehendendo a impossibilidade de resolver-me a adoptar o partido desesperado que me propozera, único que poderia assegurar-me a felicidade, se a religião do dever não fosse superior a tudo, aquella grande alma em vez de arguir-me, descendo ao nivel da vulgaridade, entendia tudo, e tudo perdoava; beijando com amor a propria mão que o feria!

Isto sem soltar uma só exprobração; generoso, terno, compassivo como um pae para uma filha querida! (TORRESÃO, 1869, p. 44 , grifos nossos)

Os adjetivos que Cecília-narradora escolhe para descrever Victor, em uma situação-limite da vida de ambos, são significativos, pois evidenciam a ausência de desejo. Além disso, ao associá-lo a uma figura paterna, deixa claro que o amor deles não está atrelado ao sexo. O beijo de despedida não é dado na boca, ou ao menos no rosto, mas nas mãos. Trata-se de um amor sem a pulsão da paixão. Ao longo da narrativa, isso fica patente, já que, frequentemente, Victor recorre a palavras geralmente associadas à pureza feminina, como "anjo" e "pomba", para se referir à Cecília.

As barreiras sociais também são um impeditivo para o sonho na idílica Itália. Cecília é rica; porém, sendo mulher, tem pouquíssimos direitos naquela sociedade 
e sabe o peso que uma decisão como essa the traria. Victor é homem, pleno de direitos; porém, sendo pobre, esbarra em entraves socioeconômicos. O diálogo entre ele e a baronesa é sintomático para compreendermos a complexidade dessa sociedade. Representante do Portugal antigo, absolutista, a baronesa valoriza a nobreza dos títulos e defende seus privilégios de classe; já Victor, representante do Portugal novo, liberal, defende a nobreza de caráter e a igualdade. Para baronesa, contudo, esses dois mundos são inconciliáveis, pois as barreiras sociais são concretas e intransponíveis.

A baronesa depois de recolher-se um instante, como para chamar em seu auxilio todo o vigor preciso, exclamou com a voz tremula de raiva, e designando a porta com gesto arrogante:

- Sáia senhor!

E não lhe passe pela idéa transpor mais o limiar d'aquella porta, que nunca devera franquear-se senão aos eguaes; evitando assim o ter de castigar grosseiras agressões.

$[\ldots]$

- Vossa excellencia é senhora, e tanto basta para que eu a respeite; mas quando o não fosse emmudeceria perante os seus ultrajes; creio provar com o meu silencio uma verdade, é que a aristocracia da alma vale pelo menos tanto como a de sangue. 
Há incontestavelmente mais nobresa no plebeu que perdôa, esquecendo a affront, por não querer descer até ella, do que no fidalgo, que não contente de the aniquilar para sempre a primeira e a ultima das suas esperanças, o põe fóra como a um lacaio; pretendendo assim cuspir uma nodoa em quem por único brasão só tem a honra.

Bem vê vossa excelência que não attingiu o seu fim, humilhar-me; quer-me parecer que me conservei aonde estava, ao passo que vossa excellencia desceu. (TORRESÃO, 1869 , p. 47-49)

Ainda que não consiga promover uma transformação total, Victor simboliza uma perturbação da ordem, pois questiona as bases que sustentam a sociedade portuguesa. Sua trajetória - pobre, porém instruído, frequentador dos salões - é uma prova de havia uma mudança em curso. Em sua fala, expõe a hipocrisia de uma sociedade que valoriza a aparência, defende seus princípios mais caros, como a liberdade e a igualdade, e não se intimida perante alguém em posição social superior. Note-se que é pela voz de um personagem masculino a crítica mais dura da narrativa. Trata-se de uma estratégia de sobrevivência da própria autora que, diante das circunstâncias vividas pelas mulheres naquela época, jamais poderia colocar na voz de Cecília, por exemplo, uma opinião tão contundente. Seria, provavelmente, condenada 
e perseguida pela opinião pública, que ainda se acostumava com obras escritas por mulheres.

No entanto, Cecília não é uma personagem passiva, que se conforma completamente com o impedimento imposto por sua tia e com os interditos morais e sociais. Ao priorizar a própria felicidade, rompe, ainda que momentaneamente, com o paradigma da mulher prudente, silenciosa e enfrenta a baronesa, recusando-se a casar com um homem que não ama:

- Basta de escravidão minha tia; não contente de aniquilar-me para sempre a felicidade pretende impôr-me o mais cruel de todos os sacrificios! illudindo assim as esperanças d'esse anjo que me deixou na terra entregue ao seu carinho! [...]

Basta de escravidão repito; e deixe-me dizerIhe minha tia, esse casamento a que annui em um excesso de loucura é absolutamente impossivel! (TORRESÃO, 1869, p. 50)

Cecília luta como pode, usa os recursos ao seu alcance. Em uma atitude ousada, ela decide conversar pessoalmente com o conselheiro, revelando-Ihe seus sentimentos mais íntimos e pedindo-Ihe, então, que desista do casamento:

Amo Victor de Andrade com um d'estes amores que surgem no arrebol da vida, para só fundarem no occaso d'ella; amor immenso santificado pelas lagrimas de ambos! 
Sei que nunca pertencerei a Victor, mas por isso mesmo não quero nem devo pertencer a outrem.

Poderia dizer-Ihe que lhe fazia esta confissão unicamente impellida pela generosidade, não querendo illudil-o dando-lhe uma esposa sem amor, um coração morto para todos os affectos, a não ser aqulle que the deu vida; bastante franca porém para não occultar a verdade atravez de artificios prefiro expor-lhe o que sinto. É porque recuo perante o enorme sacrificio de ser esposa de um homem a quem não amo; por que não posso de maneira alguma acceital-o, que the confessei os meus sentimentos. (TORRESÃO, 1869, p. 56)

Para a surpresa de Cecília, o conselheiro compreende a situação e acata a sua decisão. Na verdade, ele se mostra um personagem mais complexo, que enxerga além das convenções sociais e considera a atitude de Cecília sincera e nobre, em vez de imprudente e insolente. Torna-se, então, um aliado:

- Se não conhecesse já de sobejo a nobresa do seu caracter, bastaria o que acaba de dizer-me para comproval-a.

É digna de si, e deixe-me a vaidade de dizer de mim a franquesa com que me honrou. Tranquillise-se Cecilia... minha filha... já que Deus me nega a ventura de chamarIhe esposa, permitta-me ao menos que the dê o nome de filha; tranquillise-se, farei por corresponder á sua nobre cnfiança, tornando-me a todos os respeitos digno della. (TORRESÃO, 1869, p. 56-57) 
Cecília e Victor são, portanto, idealistas; suas ações são movidas pelo sentimento, seja de amor, seja de justiça, e têm como veículo a palavra. Defendem, cada um a seu modo, as suas convicções: ele, ao expor a hipocrisia da sociedade; ela, ao se recusar a casar. A baronesa é o símbolo das instituições arcaicas em uma sociedade em transformação. Em Viagens na minha terra, Almeida Garrett já criticava os barões:

O barão é, em quase todos os pontos, o Sancho Pança da sociedade nova.

Menos na graça...

Porque o barão é o mais desgracioso e estúpido animal da criação.

Sem excetuar a família asinina que se ilustra com individualidades tão distintas como o Ruço do nosso amigo Sancho, o asno da Pucela de Orléans e outros.

O barão (onagros-baronius de Linn., l'ânnebaron de Buf.) é uma variedade monstruosa engendrada na burra de Balaão, pela parte essencialmente judaica e usurária de sua natureza, em coito danado com o urso Martinho do Jardim das Plantas, pela parte franchinótica sordidamente revolucionária de seu caráter.

O barão é pois usurariamente revolucionário, e revolucionariamente usurário. (GARRETT, 2013, p. 91)

Na obra de Torresão, essa crítica retorna, de maneira mais evidente, quando vários personagens se encontram 
no baile. Preocupada com a saúde de Victor, autoexilado na Ilha da Madeira, Cecília não deseja sair de casa. Contudo, sua tia tenta lhe convencer com os seguintes argumentos:

Não tardará que tudo isto se divulgue, e não quero que possam suppor que um velho imbecil e demente, me causasse uma sombra sequer de despeito; além d'isso tendo-se murmurado ácerca da tua inclinação por Victor, e estando este ausente de Lisboa, desejo que, pelo menos na apparencia, te vejam risonha e feliz.

Se assim acontecer estou certa que toda a gente dirá que fomos nós quem rompemos com o conselheiro. (TORRESÃO, 1869, p. 60)

A baronesa não deixa dúvidas de que sua única preocupação é com a opinião pública, mesmo que, para dissimular, tenha que sobrepujar os sentimentos da sobrinha. Ainda que diga que pouco lhe importa o juízo alheio, Cecília sabe que precisa cumprir os protocolos sociais e ir ao baile. Nada mais sugestivo, pois, que um baile de máscaras. Enquanto todos demonstravam felicidade, Cecília-narradora confidencia aos leitores as reais emoções de Cecília-personagem:

Para maior tormento era um baile de mascaras; deleguei em Georgina poderes ilimitados, deixando ao seu cuidado a escolha e acquisição dos costumes. 
Soou a hora do sacrificio.

Atravessei aquella onda de mascarados com o riso nos labios e o desespero no coração!

$[\ldots]$

Por toda a sala vibravam esplendidos e ruidosos risos e os ditos de mais ou menos espirito. Todo este bulicio contrastava singularmente com a disposição do meu espirito, e todavia era mister a troco dos mais penosos esforços, transigir com elle. Comprehendia que o mostrar-me triste seria ir de encontro ao mais terrivel dos escolhos, o ridiculo.

Além d'isso minha tia murmuravame ao ouvido não sei que instrucções, acompanhadas de instantes supplicas para que, pelo menos apparentemente, tomasse parte da alegria geral. (TORRESÃO, 1869, p. 64-65)

A reação de Cecília, agora, é distinta da que ela demonstrou ao adentrar um baile pela primeira vez. Se antes ficou deslumbrada, agora se sente martirizada justamente pelo dever de fingir. Um fator determinante para essa mudança de ânimo é o amor, sentimento que, para ela e Victor, é sinônimo de sofrimento. Isso é comprovado pela voz da Cecília narradora, ao comparar sua existência ingênua, livre e alegre antes de amar Victor. Note-se que os sentimentos desses personagens são sempre idealizados: 
Ai! como é bella a existencia, e os seus prazeres, contemplada atravez do prisma de illusões, doiradas como um arrebol, quando o coração candido e insciente vôa risonho e livre!...

Depois o amor, esse sentimento grandioso e soberano, baptismo de fogo em que a alma adquire o direito de gosar pela faculdade de soffrer, principia ao mais das vezes envolvendo em nuvens o sol esplendido da juventude!...

E tudo isto pensava eu em quanto os mais riam e folgavam!... (TORRESÃO, 1869, p. 65)

A máscara, que a sufocava e ocultava seus sentimentos, pode, enfim, ser retirada. No entanto, ainda deve manter, ao lado de sua tia, o dito bom comportamento social: "Minha tia acolheu-me com um sorriso indulgente, recordando-me em voz alta, e com premeditada affectação, o damno que poderia provir-me do excesso de dançar" (TORRESÃO, 1869, p. 66).

A retirada das máscaras também permite que Cecília questione a imagem que havia feito de Leonor, também presente no baile. Se antes, por acreditar que dividiam o amor do mesmo homem, considerava-a inimiga, agora as certezas de Cecília estão abaladas. É Georgina, porém, que insiste em caracterizar Leonor como uma mulher sedutora e dissimulada:

- É possivel que a alma d'esta mulher seja má?!... 
- Oh! estas ingenuas que estudam ao espelho a melhor maneira de illudir os incautos, redarguiu Georgina sorrindo ironicamente, sempre colhem alguma vantagem das suas aturadas lucubrações.

Ahi estás tu já disposta a crer que te enganei, quando a verdade é que essa mulher, abusando da fascinação que a sua bellesa exerce, attrahe unicamente impellida pelo desejo de escarnecer quem tem a loucura de affeiçoar-se-lhe. Victor foi dos illudidos; e tu, se o fores tambem, poupar-lhe-has o incommodo de idear novos ardis para vingarse. (TORRESÃO, 1869, p. 67)

Georgina se diverte com o plano de alguns homens para comprometer a reputação de Leonor. Cecília, no entanto, indigna-se e decide ajudar a vítima. Ao colocar-se no lugar de outra mulher, a personagem esquece as supostas diferenças que havia entre elas. Cecília sabe a importância do julgamento alheio para a imagem de uma senhora:

Indignada, e mal podendo crêr o que ouvia, comparava a alma nobre e superior de Victor com a desses peralvilhos ociosos que consomem a vida não só em inuteis puerilidades, mas tambem abocanhando indistinctamente $\mathbf{o}$ mais sagrado dos direitos, a reputação! (TORRESÃO, 1869, p. 70 , grifos nossos)

A ironia da narrativa é que um desses homens é um visconde, "notavel por suas loucuras" (TORRESÃO, 1869, 
p. 70), o que, de maneira sutil, desconstrói o discurso da baronesa algumas páginas atrás. Prova de que título não é sinônimo de boa índole.

Outra máscara retirada no baile é a de Georgina. Leonor revela a Cecília a verdade sobre a prima:

Fechava os olhos á evidencia; queria duvidar das palavras de Leonor, porém por uma notavel revelação intima, o passado surgia com todos esses insignificantes mas eloquentes indicios, aos quaes insciente e credula até alli não ligára valor!

Os singulares olhares que surprehendera em Georgina dirigidos a Victor; a notavel dissonancia de muitas das suas palavras; a alegria que patenteára no dia em que a baronesa annunciára o meu projectado casamento; a tenacidade com que tentára afastar-me d'aquelle baile onde encontraria Leonor; finalmente feriam-me todos esses mil nadas que até então haviam passado absolutamente desapercebidos!

E todavia a despeito da rasão o coração queria ainda duvidar!!... (TORRESÃO, 1869, p. 76-77, grifos nossos)

Em seguida, é a própria Georgina quem diz a verdade sobre si mesma:

- Ah! não sabes quanto odio e ciume tenho devorado em silencio desde que um acaso fatal nos aproximou... 
- E eu que o havia abençoado porque me concedêra uma irmã!...

- Devias amaldiçoal-o porque te dava uma rival, e mais tarde uma inimiga.

Julgavas, mulher ingenua e credula, compensar tudo com essas miseraveis dadivas, cada uma das quaes era um desafio arremessado á minha pobresa pela tua insolente riquesa!?

Quantas vezes chorei de raiva desejando calcal-as aos pés, cuspir n'ellas o desespero que me despedaçava!...

Não comprehendes que o amor proprio humilhado, o ciume, e o odio são feridas cuja cicatriz é indelevel?...

Não bastou esmagares-me com a tua pretendida superioridade moral, com a tua opulencia, roubaste-me também a minha única felicidade, o amor de Victor!...

Não há virtude por mais acrisolada que resiste a tão dura prova.

E ainda ousas accusar-me quando sou eu que devo pedir-te severas, e restrictas contas; e julgavas-me tão inerte, tão miseravel, tão imbecil que podesse amar-te!!...

Oh! esta mascara já me incommodava!

Soou afinal o momento de extravasar o fel que ha tanto me enchia o peito, e dizer-te odeio-te! odeio-te!... (TORRESÃO, 1869, p. 80) 
Considerem-se agora as motivações de Georgina. Pobre, nutria ódio pelo que Cecília representava: riqueza, hierarquia, superioridade moral, opulência. A ajuda oferecida pela prima pode ser vista, nesse contexto, como uma esmola. Além disso, Victor a desprezou quando conheceu Cecília. Sentia-se humilhada, ultrajada em todas as formas. Esse diálogo, agressivamente franco, representa um choque de realidade nas ilusões exacerbadamente românticas de Cecília. Na verdade, a narrativa mostra que, naquele momento, não é possível uma conciliação entre as classes. Isso se verifica na insurgência de Victor contra a baronesa e na explosão de ódio de Georgina contra Cecília. Victor é mais comedido em suas palavras; Georgina, não. Ela se encontra num estado de revolta contra a burguesia, escancarando um visível abismo econômico e social.

Havia indícios sobre o caráter de Georgina, mas Cecília não percebeu, ou escolheu não notar justamente porque idealizava a amizade com a prima, acreditando que ela era perfeita. Ao questionar a veracidade de fatos, dizendo para si mesma que "o mundo não pode ser tão mau" (TORRESÃO, 1869, p. 77), Cecília reforça que suas ações são pautadas pelo idealismo. A própria narrativa, contudo, questiona esse idealismo, marcante no casal protagonista. 
Victor, o mais idealista dos personagens, tem um fim trágico. Sem conseguir abrir mão de seus princípios para sobreviver naquela sociedade, ele foge. A princípio, para a Ilha da Madeira, onde se intensifica o sofrimento amoroso e morre. A afirmação irônica de Cecília, quando eles se encontram no início da narrativa, antecipa, para os leitores, o destino de Victor: "Creio para sempre extincta a raça dos Werthers; e além de ridiculos, impossiveis os suicidios por amor" (TORRESÃO, 1869, p. 33). Ainda que não tenha repetido todas as ações do personagem de Goethe, ao escolher o caminho do sofrimento extremo, Victor, consequentemente, abdica de sua vida.

Cecília, embora predominantemente idealista e ingênua, não recorre ao escapismo; busca maneiras para amenizar sua situação. Recusa-se a casar, mesmo que, para tal, tivesse que enfrentar a tia e recorrer à ajuda do futuro noivo, o conselheiro. Ao descobrir que Victor morreu, sofre, adoece, mas não sucumbe.

Em virtude das prescripções dos medicos conduziram-me para Lisboa, indo habitar a casa de Leonor a Buenos-Ayres.

Deixei-me levar como um automato; não sentia que vivia senão pela amisade cada vez mais viva que me ligava a Leonor, a cuja desvelada dedicação era 
incontestavelmente devida a minha especie de resurreição. (TORRESÃO, 1869, p. 87)

Órfã, Cecília busca o afeto materno, sem sucesso, na tia, na prima, mas só o encontra em Leonor. É ela quem a ampara quando, após a morte da baronesa, Cecília fica só. No entanto, a companhia da nova amiga não é suficiente para os códigos morais da época. Cecília precisa da proteção masculina.

Rica, com 20 annos apenas, achei-me no mundo só, abandonada a mim mesma, sem ter um braço protector para amparar-me, uma rasão madura para dirigir-me! [...]

O conselheiro, pouco tempo depois da morte de minha tia, que nunca lhe havia perdoado o proceder de que ignorára sempre a origem, continuou visitando-nos com a assiduidade d'outro tempo.

Era um caracter incapaz d'essa sublimidade poetica, heroica, e exaltada das naturezas privilegiadas; porém em troca havia n'elle tanta bondade e singeleza; tanta franqueza e despretensão na physionomia, que chegava a fazer esquecer a sua fealdade. (TORRESÃO, 1869, p. 90-91)

Ao final da narrativa, tem-se uma inusitada configuração familiar. Cecília e o conselheiro se casam, tendo amizade como pilar da união, e Leonor como testemunha e companhia constante. Não é a família perfeita, mas é a família possível. 
Em meio a estratégias de modéstia e moralidade, exigidas pelas circunstâncias, Guiomar Torresão apresenta reflexões sobre as contradições de um período de transição política e social, em que o novo não está plenamente atingido e o antigo não está totalmente superado. A autora congrega, nos personagens, as características desse momento de instabilidade: a baronesa representa a reação à mudança; Vitor, o ideal de liberdade; Cecília, a protagonista, o equilíbrio entre os extremos, mas que, nas veredas do texto, projeta a ideia de um futuro em que as mulheres terão liberdade em suas escolhas.

\section{REFERÊNCIAS}

ALMEIDA, Fialho de. Figuras de Destaque. Lisboa: Livraria Clássica Editora, 1923. CASTELO BRANCO, Camilo. Carta-prefácio. In: TORRESÃO, Guiomar. No Theatro e na sala. Camilo Castelo Branco. Lisboa: David Corazzi, 1881. GARRETT, Almeida. Viagens na minha terra. Sérgio Nazar David (Coord.). Rio de Janeiro: Nova Fronteira, 2013.

LOPES, Ana Maria Costa. Imagens da mulher na imprensa feminina de oitocentos: percursos de Modernidade. Lisboa: Quimera, 2005. MACHADO, Julio Cesar. Introducção. In: TORRESÃO, Guiomar. Uma alma de mulher: romance original. Lisboa: Typ. de J. G. de Sousa Neves, 1869. ORTIGÃO, Ramalho. As Farpas. Lisboa: Thypografia Universal, v. 10, agosto/setembro de 1877.

PERROT, Michele (Org.). História da vida privada, v. 4: da Revolução Francesa à Primeira Guerra. São Paulo: Companhia das Letras, 2009. TORRESÃO, Guiomar. Uma alma de mulher: romance original, precedido de uma introdução de Julio Cesar Machado. Lisboa: Typ. de J. G. de Sousa Neves, 1869. 
TORRESÃO, Guiomar. No Theatro e na sala, com uma carta-prefácio de Camilo Castelo Branco. Lisboa: David Corazzi, 1881.

VAQUINHAS, Irene. Senhoras e mulheres na sociedade portuguesa do século XIX. Lisboa: Edições Colibri, 2000.

\section{Juliana de Souza Mariano}

Doutora em Letras pela UERJ (2020).

Professora substituta de Literaturas Portuguesa e Africanas UFRRJ/IM, nível graduação.

Lattes: http://lattes.cnpq.br/6404345126457449

E-mail: juli.smariano@gmail.com

ORCID iD: https://orcid.org/0000-0002-9284-0837 